\title{
Pengembangan Modul Matematika Berbasis Kontekstual Terintegrasi Ilmu Keislaman
}

\author{
Annisah Kurniati \\ Universitas Islam Negeri Sultan Syarif Kasim Riau \\ Jl. Subrantas KM 15, Rimba Panjang, Tambang, Kota Pekanbaru, Riau 28293, Indonesia \\ E-mail:annisa.kurniati@gmail.com
}

\begin{abstract}
This study aims to analyze, describe the validity, and the practicalities of the development of mathematics modules integrated contextually based on Islamic science students. This type of research is the development of research (research and development $/ R \& D$ ). Subjects in the trial that high school students IT Az-Zuhra Islamic School. The study design using the ADDIE research model. As the name implies, the model ADDIE consists of five main phases or stages, namely (A) nalysis, (D) esign, (D) evelopment, (I) mplementation, and (E) valuation. Type of data collected in this study is primary data, i.e. data obtained directly from the questionnaire. Data collection instrument in the form of questionnaire test questionnaire validity and practicalities. Data were analyzed with descriptive analysis techniques. The results showed that the modules integrated mathematics contextually based Islamic science is valid and practical to use.
\end{abstract}

Keywords: Learning Module, Kontextual Approach, Integration of Islamic Studies.

\begin{abstract}
Abstrak
Penelitian ini bertujuan untuk menganalisis, mendeskripsikan validitas, dan praktikalitas pengembangan modul matematika berbasis kontekstual terintegrasi ilmu keislaman pada siswa. Jenis penelitian yang digunakan adalah penelitian pengembangan (research and development/R\&D). Subjek dalam uji coba yaitu siswa SMA IT Az-Zuhra Islamic School. Rancangan penelitian menggunakan model penelitian ADDIE. Sesuai dengan namanya, model ADDIE terdiri dari lima fase atau tahap utama, yaitu (A)nalysis, (D)esign, (D)evelopment, (I)mplementation, dan (E)valuation. Jenis data yang diambil dalam penelitian ini adalah data primer, yaitu data yang diperoleh langsung dari angket. Instrumen pengumpulan data berupa angket uji validitas dan angket uji praktikalitas. Data yang diperoleh kemudian dianalisis dengan teknik analisis deskriptif. Hasil penelitian menunjukan bahwa modul matematika berbasis kontekstual terintegrasi ilmu keislaman ini valid dan praktis untuk digunakan.
\end{abstract}

Kata Kunci: Modul Pembelajaran, Pendekatan Kontekstual, Integrasi Ilmu Keislaman. 


\section{Pendahuluan}

Pembelajaran yang efektif ditandai dengan adanya proses belajar dalam diri siswa, adanya wawasan berpikir yang beragam sehingga siswa dapat mempelajari berbagai konsep dan mampu mengkaitkannya dengan kehidupan nyata. Namun sebaliknya, pembelajaran pada umumnya cenderung memperlakukan siswa berstatus sebagai obyek. Guru berfungsi sebagai pemegang otoritas tertinggi keilmuan dan indoktrinator. Materi bersifat subject-oriented, dan manajemen bersifat sentralistis. Proses yang demikian menyebabkan siswa mengisolir diri dari kehidupan nyata yang ada di luar sekolah. Siswa terlalu terkonsentrasi pada pengembangan intelektual yang tidak berjalan dengan perkembangan siswa secara individu sebagai satu kesatuan yang utuh dan berkepribadian. Akibatnya sebagian besar dari siswa tidak mampu menghubungkan antara apa yang dipelajari dengan bagaimana pengetahuan tersebut akan dipergunakan atau dimanfaatkan dalam kehidupan.

Untuk mengatasi masalah tersebut, pembelajaran sebaiknya diberikan dengan memperhatikan konteks siswa dan mengaitkan materi dengan kehidupan nyata. Konteks nyata dari kehidupan siswa meliputi latar belakang fisik, keluarga, keadaan sosial, politik, agama, budaya dan kenyataan hidup lainnya. ${ }^{1}$ Pembelajaran yang dilakukan dengan memperhatikan konteks siswa dan mengaitkan materi dengan kehidupan nyata akan dapat membantu pemerintah dalam rangka meningkatkan mutu pendidikan nasional yang berfungsi mengembangkan kemampuan dan mengembangkan watak serta peradaban bangsa yang bermartabat dalam rangka mencerdaskan kehidupan bangsa, yang bertujuan untuk berkembangnya potensi siswa agar menjadi manusia yang beriman dan bertakwa kepada Tuhan yang Maha Esa, berakhlak mulia, sehat, berilmu, cakap, kreatif, mandiri, dan menjadi warga negara yang demokratis serta bertanggung jawab. ${ }^{2}$

Ada begitu banyak pendekatan pembelajaran yang memperhatikan konteks siswa dan mengaitkan materi dengan kehidupan nyata. Salah satunya adalah pendekatan kontekstual. Pendekatan kontekstual fokus pada siswa sebagai pembelajar yang aktif, dan memberikan rentang yang luas tentang peluang-peluang belajar bagi yang menggunakan kemampuankemampuan akademik untuk memecahkan masalah-masalah kehidupan nyata yang kompleks. ${ }^{3}$

${ }^{1}$ Moch. Masykur Ag and Abdul Halim Fathoni, Mathematical Intelegent Cara Cerdas Melatih Otak Dan Menanggulangi Kesulitan Belajar (Yogyakarta: Arruz Media, 2008), 58.

2 “Undang-Undang Sistem Pendidikan Nasional No 20 Tahun 2003, Bab II, Pasal 3," n.d., 8-9.

${ }^{3}$ Depdiknas, Pendekatan Kontekstual (Contextual Teaching and Learning) (Jakarta: Direktorat Pendidikan Lanjutan Pertama, 2002), 15. 


\section{Pengembangan Modul Matematika ...}

Akan tetapi, menciptakan suatu pembelajaran yang menjadikan siswa memiliki keseimbangan antara Iman dan Takwa (IMTAK) dan Ilmu Pengetahuan dan Teknologi (IPTEK) bukanlah hal yang mudah. Apalagi hal ini diimplementasikan pada pembelajaran matematika yang kebanyakan orang menganggap bahwa matematika merupakan subjek sekuler dan tidak ada kaitannya dengan ilmu agama.

Pernyataan tersebut dibenarkan oleh Ali yang menyatakan bahwa Kurikulum pendidikan umum (sains) sering dianggap sebagai "subjek sekuler". ${ }^{4}$ Padahal, menyelaraskan dan memadukan ilmu agama dengan memperhatikan konteks siswa dan mengaitkan materi dengan kehidupan nyata pada pembelajaran matematika sangat penting. Dengan menyelaraskan dan memadukan aspek tersebut, akan semakin meningkatkan kemampuan, keimanan dan ketakwaan siswa pada Tuhan Yang Maha Esa yang merupakan salah satu tujuan pendidikan. Untuk mewujudkan tujuan tersebut dan mengaplikasikan dalam matematika salah satunya adalah dengan mengaitkan persoalan matematika dalam kehidupan nyata dan mengintegrasikan ilmu keislaman dalam pembelajaran matematika.

Integrasi ilmu keislaman dalam pembelajaran menjadi ciri khas di lembaga pendidikan Islam. Setiap kegiatan termasuk kurikulum dan proses pembelajaran, harus dilakukan dengan mengaitkan ilmu keislaman, termasuk oleh guru. Hal ini dipertegas oleh Siti Mahfudzoh bahwa kepada para pengkaji ilmu matematika diharapkan tidak melupakan Al-Qur'an yang diyakini sebagai sumber dasar semua ilmu. Begitu pula para pengkaji AlQur'an diharapkan tidak melupakan matematika yang merupakan ilmu yang terkandung dalam Al-Qur'an. ${ }^{5}$ Abdussakir juga mengungkapkan bahwa antara Matematika dan Al-Qur'an saling berkaitan. Untuk mempelajari matematika (ilmu hitung) sumbernya Al-Qur'an. Sedangkan untuk memahami ayat-ayat Kauniyah yang terkandung dalam Al-Qur'an maka diperlukan matematika. ${ }^{6}$

${ }^{4}$ Ali, "Integrasi Pendidikan Nilai Islam Dalam Pembelajaran Matematika Di Sekolah Menengah Pertama/Madrasah Tsanawiyah Sebagai Upaya Pembinaan Akhlak Siswa" (Internasional ISCSM-2, ITB Bandung, 2013).

${ }^{5}$ Siti Mahfuzoh, "Pengaruh Integrasi Islam Dan Sains Terhadap Matematika," in Proseding Seminar Nasional Matematika Dan Pendidikan Matematika Yogyakarta (Seminar Nasional Matematika dan Pendidikan Matematika Yogyakarta, Yogyakarta, 2011), 38.

${ }^{6}$ Abdusysyakir, Ada Matematika Dalam Al-Qur'an (Malang: UIN Malang Press, 2006), 13.

Al-Khwarizmi - 45 
Berdasarkan observasi yang peneliti lakukan di beberapa Madrasah Aliyah dan sekolah Islam Terpadu di Pekanbaru dan wawancara dengan guru matematika, diketahui bahwa pola mengajar guru masih didominasi oleh metode ceramah, karena mengacu pada materi yang ada pada kurikulum. Dilihat dari pendekatan mengajar yang digunakan, tampak cara penyampaian materi oleh guru terlalu abstrak. Jarang sekali guru mengaitkan materi yang dibahasnya dengan masalah-masalah atau isu-isu yang terjadi di sekitar siswa. Selain itu, pengintegrasian ilmu keislaman dalam materi matematika belum optimal. Integrasi Islam dilaksanakan masih sebatas pada nuansa islami seperti memisahkan tempat duduk antara siswa laki-laki dan perempuan, berdoa dan membaca Al-Qur'an sebelum memulai pelajaran dan pemberian nasehat.

Sumber belajar yang digunakan guru merupakan buku dari penerbit atau buku paket. Jika dilihat dari buku yang digunakan guru, buku tersebut bukan merupakan buku berbasis kontekstual. Hal ini dikarenakan buku tersebut belum memenuhi aspek-aspek yang ada pada pembelajaran kontekstual yaitu aspek kontruktivisme, penemuan, bertanya, masyarakat belajar, pemodelan, refleksi dan penilaian yang sebenarnya. Buku yang digunakan guru lebih menekankan pada pemahaman konsep. Siswa diberikan konsep tanpa siswa sendiri mencari konsep tersebut. Padahal tujuan pembelajaran matematika tidak hanya siswa paham terhadap konsep, akan tetapi juga memiliki kemampuan untuk memecahkan permasalahan dalam matematika. Selain itu, buku ataupun modul dan bahan ajar lainnya yang digunakan oleh guru tidak ada yang mengintegrasikan materi matematika dengan ilmu keislaman.

Untuk mengatasi permasalahan yang telah dikemukakan, peneliti mencoba untuk mengembangkan suatu bahan ajar matematika yang dikaitkan dengan kehidupan nyata dan yang terintegrasi dengan nilai keislaman yaitu dengan mengkaji matematika dalam Islam yang terkadung dalam Al-Qur'an dan Hadist. Bahan ajar yang akan dikembangkan peneliti yaitu modul matematika berbasis kontekstual terintegrasi ilmu keislaman. Modul ini dikhususkan pada materi Sistem Persamaan dan Pertidaksamaan Linear.

Materi Sistem Persamaan dan Pertidaksamaan Linear merupakan materi yang disajikan pada kelas X. Penelitian ini dirangkum dalam judul "Pengembangan Modul Matematika Berbasis Kontekstual Terintegrasi Ilmu Keislaman". 


\section{Kerangka Teoretis}

\section{Kajian Mengenai Penggunaan Modul Pembelajaran}

Modul adalah suatu kesatuan yang utuh, terdiri dari serangkaian kegiatan belajar, yang secara nyata telah memberikan hasil belajar yang efektif dalam mencapai tujuan yang telah dirumuskan secara jelas dan spesifik. ${ }^{7}$ Modul merupakan satu unit program belajar mengajar terkecil yang unsur-unsur modul terdiri dari pedoman guru, lembar kegiatan siswa, lembar kerja, kunci lembar jawaban, lembaran tes, kunci lembaran tes. ${ }^{8}$

Berdasarkan penelitian Rully R. Oroh dengan judul Peningkatan Hasil Belajar Siswa Melalui Penggunaan Bahan Ajar. ${ }^{9}$ Hasil penelitian ini menunjukkan bahwa pola belajar dengan menggunakan modul ajar, relatif dapat meningkatkan sikap kemandirian, efektifitas belajar siswa, dan meningkatkan prestasi belajar siswa. Penelitian yang dilakukan Ni Putu Prita Nugrahini dengan judul Pengembangan Modul Ajar Aplikasi Basis Data dengan Model Pembelajaran SQ3R untuk Siswa Kelas X Rekayasa Perangkat Lunak di SMK Negeri 1 Negara. ${ }^{10}$ Berdasarkan hasil penelitian, respon siswa terhadap pengembangan modul ajar dapat dikategorikan sangat positif. Respon sangat positif tersebut menunjukkan bahwa siswa senang dan termotivasi dalam belajar dengan menggunakan modul ajar.

Penelitian yang dilakukan oleh Muhammad Habibi dengan judul Pengembangan Modul Pecahan Berbasis Konstruktivisme dengan Sisipan Karikatur untuk Kelas IV Sekolah Dasar. ${ }^{11}$ Hasil penelitian ini menunjukkan bahwa modul pecahan berbasis konstruktivisme dengan sisipan karikatur untuk kelas IV SD berada pada kategori valid baik ditinjau dari aspek didaktik, konstruk, maupun teknis. Jadi modul yang dihasilkan dapat dikembangkan sebagai media pembelajaran matematika.

${ }^{7}$ Suryosubroto, Sistem Pengajaran Dengan Modul (Yogyakarta: Bina Aksara, 1983), 21.

${ }^{8}$ Joseph Mbulu, Pengajaran Individual(Malang: Yayasan Elang Mas, 2001), 41.

${ }^{9}$ Rully R. Oroh, "Peningkatan Hasil Belajar Siswa Melalui Penggunaan Bahan Ajar" 2, no. 1 (March 2011).

${ }^{10}$ Ni Putu Prita Nugrahini, "Pengembangan Modul Ajar Aplikasi Basis Data Dengan Model Pembelajaran Sq3r Untuk Siswa Kelas X Rekayasa Perangkat Lunak Di SMK Negeri 1 Negara," JANAPATI: Jurnal Nasional Pendidikan Teknik Informatika 1, no. 3 (Desember 2012).

11 Muhammad Habibi, "Pengembangan Modul Pecahan Berbasis Konstruktivisme Dengan Sisipan Karikatur Untuk Kelas IV Sekolah Dasar," in Prosiding Seminar Nasional Pendidikan Matematika - UNINUS, vol. 2 (Bandung: Uninus Bandung, 2014).

Al-Khwarizmi - 47 
Dari beberapa pendapat, dapat dijelaskan bahwa penggunaan modul sebagai bahan ajar pada pembelajaran matematika dapat meningkatkan kemampuan belajar matematika. Selain itu, penggunaan modul juga dapat meningkatkan motivasi dan sikap positif dalam belajar matematika.

\section{Kajian Mengenai Pendekatan Kontekstual}

Model pembelajaran yang menggunakan pendekatan kontekstual merupakan konsep belajar yang membantu guru mengaitkan antara materi pembelajaran dengan situasi dunia nyata siswa dan mendorong siswa membuat hubungan antara pengetahuan yang dimilikinya dengan penerapannya dalam kehidupan mereka sehari-hari. ${ }^{12}$ Menggunakan konteks artinya dalam pembelajaran menggunakan masalah kontekstual yang berasal dari lingkungan siswa yang nyata dan dapat disajikan di awal, di tengah atau di akhir pembelajaran. ${ }^{13}$

Studi terkait dengan penelitian ini diantaranya adalah penelitian yang dilakukan oleh Ni Nyoman Parwati dengan judul Pembelajaran Matematika dengan Pendekatan Kontekstual pada Siswa SMP Negeri 2 Singaraja ${ }^{14}$. Penelitian ini menjelaskan pendekatan kontekstual sangat cocok diterapkan pada pembelajaran matematika. Hal terbukti dari hasil penelitian menunjukan bahwa hasil belajar matematika siswa meningkat. Selain itu, penelitian yang dilakukan oleh Hasanah dengan judul Analisis Kemampuan Penalaran Matematika Siswa SMP melalui Pembelajaran dengan Pendekatan Kontekstual. Penelitian ini menunjukan bahwa kemampuan penalaran matematika siswa dapat ditingkatkan melalui pendekatan kontekstual. ${ }^{15}$

12 Masnur Muchlis, Ktsp, Pembelajaran Berbasis Kompetensi Dan Kontekstual (Jakarta: Bumi Aksara, 2007), 7.

${ }^{13}$ Pambudi, S. D, "Berbagai Alternatif Model Dan Pendekatan Dalam Pembelajaran Matematika" 1, no. 2 (2007): 39-45.

${ }^{14}$ Ni Nyoman Parwati, "Pembelajaran Matematika Dengan Pendekatan Kontekstual Pada Siswa SMP Negeri 2 Singaraja (Paradigma Baru Pembelajaran Matematika Sekolah Berorientasi KBK)," Jurnal Pendidikan Dan Pengajaran IKIP Negeri Singaraja 4 (Oktober 2006): 203-223'.

15 Hasanah, "Analisis Kemampuan Penalaran Matematika Siswa SMP Melalui Pembelajaran Dengan Pendekatan Kontekstua," Program Studi Pendidikan Matematika PPS UNIMED 4, no. 2 (Desember 2011): 148-64. 


\section{Pengembangan Modul Matematika ...}

Penelitian oleh Zulkardi dengan judul Pengembangan Perangkat Pembelajaran Berbasis Kontekstual Pokok Bahasan Turunan di Madrasah Aliyah Negeri 3 Palembang. ${ }^{16}$ Penelitian ini menunjukan bahwa perangkat pembelajaran berbasis kontekstual dapat digunakan oleh siswa dengan baik. Hal ini ditunjukan dengan hasil analisis data tes hasil belajar pokok bahasan turunan pada pembelajaran matematika menunjukan nilai rata-rata siswa telah mencapai Kriteria Ketuntasan Minimal (KKM). Hal ini berarti bahwa pengembangan perangkat pembelajaran berbasis kontekstual yang dilakukan termasuk kategori efektif.

\section{Kajian Mengenai Integrasi dengan Keilmuan Islaman}

Kajian oleh Zubaidah yang berjudul Integrasi Nilai Pendidikan Islam dalam Pendidikan Umum Sebagai Revitalisasi Pendidikan Islam. ${ }^{17}$ Pada kajian ini dijelaskan contoh-contoh integrasi antara nilai-nilai Islam dengan pendidikan umum serta bagaimana perubahannya terhadap pendidikan.

Kajian oleh Abdussakir yang berjudul Pentingnya Matematika dalam Pemikiran Islam. Dalam kajiannya dinyatakan bahwa matematika dan ilmu keislaman memiliki kaitan yang sangat erat. Untuk mempelajari dan memahami ilmu keislaman yang terkandung pada Al-Qur'an maka diperlukan matematika. Matematika juga mampu memberikan pendekatan yang lebih dalam untuk memahami ayat-ayat Al-Qur'an. ${ }^{18}$

Selanjutnya studi literatur yang dilakukan Siti Mahfuzoh dengan judul Pengaruh Integrasi Islam dan Sains terhadap matematika. ${ }^{19}$ Studi literatur ini merekomendasikan agar perlu kajian lebih lanjut mencari hubungan matematika dalam Al-Qur'an. Kajian oleh Mimi Hariyani yang berjudul Strategi Pembelajaran Matematika Madrasah Ibtidaiyah Berintegrasi Nilainilai Islam. ${ }^{20}$ Kajian ini memaparkan beberapa langkah strategi pembelajaran yang dikaitkan dengan pengintegrasian nilai-nilai Islam yang dapat dilakukan dalam pembelajaran matematika.

${ }^{16}$ Zulkardi, "Pengembangan Perangkat Pembelajaran Berbasis Kontekstual Pokok Bahasan Turunan Di Madrasah Aliyah Negeri 3 Palembang” 3, no. 1 (January 2009).

17 Zubaidah Amir MZ, "Integrasi Nilai Pendidikan Islam Dalam Pendidikan Umum Sebagai Revitalisai Pendidikan Islam," Jurnal Potensia Fakultas Tarbiyah Dan Keguruan Uin Suska Riau12, no. 1 (June 2013).

18 Abdusysyakir, "Pentingnya Matematika Dalam Pemikiran Islam" (The Role of Sciences and Technology in Islamic Civilization, UIN Malang, 2009).

${ }^{19}$ Mahfuzoh, “Pengaruh Integrasi Islam Dan Sains Terhadap Matematika," 38.

20 Mimi Hariyani, "Strategi Pembelajaran Matematika Madrasah Ibtidaiyah Berintegrasi Nilai-Nilai Islam” 12, no. 2 (Desember 2013).

Al-Khwarizmi - 49 
Selain itu, kajian oleh Suparni yang berjudul Pengembangan Karakter Bangsa Melalui Integrasi Nilai Keislaman dalam Pembelajaran Matematika. Kajian ini merupakan studi kasus dalam pembelajaran matematika terintegrasi pendidikan keislaman. Pada studi kasus ini, merekomendasikan pentingnya penanaman nilai karakter keislaman dalam pembelajaran matematika. ${ }^{21}$

Penelitian Zubaidah melalui Pengembangan Perangkat Pembelajaran Matematika Berbasis Konsep Islami Pada siswa kelas V Sekolah Dasar meyatakan valid dan praktis serta efektif, namun penelitiannya hanya difokuskan pada konsep pengenalan ilmu faraid yang berkaitan dengan materi pecahan di sekolah dasar. ${ }^{22}$ Sebaiknya guru memiliki panduan khusus sebagai bahan ajar yang terintegrasi dengan keislaman di setiap jenjang pendidikan salah satunya seperti modul sehingga penelitian itu merekomendasikan pentingnya dilakukan pengembangan bahan ajar pada setiap jenjang pendidikan.

Dari paparan yang telah dijelaskan dan berdasarkan penelitian serta studi kasus, peneliti mencoba untuk mengembangkan bahan ajar berupa modul matematika berbasis kontekstual terintegrasi ilmu keislaman yang dapat dikaji dari Alqur'an dan Hadist.

\section{Metode Penelitian}

Adapun jenis penelitian yang digunakan adalah penelitian pengembangan (research and development/R\&D). Objek penelitian adalah modul matematika berbasis kontekstual terintegrasi ilmu keislaman. Subjek dalam uji coba yaitu siswa SMA IT Az-Zuhra Islamic School. Rancangan penelitian menggunakan model penelitian ADDIE. Sesuai dengan namanya, model ADDIE terdiri dari lima fase atau tahap utama, yaitu (A) nalysis, (D)esign, (D)evelopment, (I)mplementation,dan (E)valuation. ${ }^{23}$ Kelima fase atau tahap dalam model ADDIE, perlu dilakukan secara sistematik.

${ }^{21}$ Suparni, "Pengembangan Karakter Bangsa Melalui Integrasi Nilai Keislaman Dalam Pembelajaran Matematika," in Prosiding Seminar Nasional Penelitian, Pendidikan, Dan Penerapan MIPA, Fakultas MIPA (Seminar Nasional Penelitian, Pendidikan, dan Penerapan MIPA, Fakultas MIPA, Yogyakarta, 2012).

22 Zubaidah Amir MZ, "Pengembangan Perangkat Pembelajaran Matematika Berbasis Konsep Islami Pada Siswa Kelas V Sekolah Dasar,” 2009, LPP UIN Suska Riau.

23 Benny A.Pribadi, Desain Dan Pengembangan Program Pelatihan Berbasis Kompetensi (Jakarta: Prenada Media Group, 2014), 23. 
Dalam pengembangan modul ini, prosedur pengembangan yang dilakukan terdiri atas lima tahap, yakni:

1. Analisis (Analysis)

Langkah analisis terdiri atas dua tahap, yaitu analisis kinerja atau performanse analysis dan analisis kebutuhan atau need analysis. Tahapan ini dijelaskan secara rinci yaitu :Analisis kinerja dilakukan untuk mengetahui dan mengklarifikasi apakah masalah kinerja yang dihadapi memerlukan solusi berupa penyelenggaraan program atau perbaikan menajemen. ${ }^{24}$. Permasalahan yang dihadapi dalam penelitian ini adalah masih terbatasnya penggunaan bahan ajar atau modul matematika berbasis kontekstual terintegrasi ilmu keislaman yang digunakan dalam pembelajaran matematika. Sedangkan analisis kebutuhan merupakan langkah yang diperlukan untuk menentukan kemampuan-kemampuan atau kompetensi yang perlu dipelajari oleh siswa untuk meningkatkan hasil belajar.

2. Perancangan (Design)

Pada langkah perancangan (design) disusun modul pada materi himpunan dan logika. Langkah-langkah rancangan penelitian yaitu:

a. Menetapkan judul modul. Judul modul ditentukan berdasarkan kompetensi dasar, indikator-indikator, dan materi pembelajaran yang tercantum dalam kurikulum.

b. Menyiapkan buku-buku sumber dan buku referensi lainnya. Pengumpulan materi dengan menganalisis silabus, RPP dan buku teks Matematika. Mereviuw literatur Konsep pengintegrasian, Tafsir AlQur'an dan Hadist nabi

c. Melakukan identifikasi terhadap kompetensi dasar berdasarkan kurikulum, serta merancang bentuk kegiatan pembelajaran yang sesuai.

d. Mengidentifikasi indikator pencapaian kompetensi dan merancang bentuk dan jenis penilaian yang akan disajikan.

e. Merancang modul.

${ }^{24}$ Benny A.Pribadi, Model Desain Sistem Pembelajaran (Jakarta: Dian Rakyat, 2009), 128.

Al-Khwarizmi - 51 


\section{Pengembangan (Development)}

Tahapan pengembangan modul matematika berbasis kontekstual terintegrasi ilmu keislaman berdasarkan hal-hal berikut:

a. Berbentuk media cetak.

b. Dirancang secara menarik, bervariasi, dan komunikatif.

c. Dilengkapi dengan informasi berupa teks dan gambar.

d. Disusun berdasarkan format penulisan yang baik.

e. Materi dalam modul disusun melalui pendekatan pembelajaran berbasis kontekstual dan terintegrasi ilmu keislaman.

4. Implementasi (Implementation)

Langkah selanjutnya adalah menguji keefektifan praktikalisasi modul di kelas. Desain yang peneliti gunakan yaitu desain one-shot case study. Rancangan one-shot case study disebut juga rancangan one-group posttestonly design. ${ }^{25}$ Praktikalitas merupakan tingkat kepraktisan prototipe yang digunakan siswa, dan guru. Kegiatan ini dilakukan untuk mengetahui sejauh mana manfaat, kemudahan penggunaan dan efisiensi waktu. Langkahlangkah uji kepraktisan media sebagai berikut:

a. Memberi pengarahan cara pengisian angket

b. Peneliti memberikan modul

c. Membaca dan memahami modul

d. Mengisi angket yang sudah berisi pernyataan mengenai pembelajaran berbasis kontekstual terintegrasi ilmu keislaman.

5. Evaluasi (Evaluation)

Pada langkah evaluasi ini bertujuan untuk menganalisis kelayakan modul yang dikembangkan pada tahap implementasi serta melakukan revisi produk II berdasarkan evaluasi pada saat uji coba lapangan. Data-data yang diperoleh dianalisis untuk mengetahui revisi yang perlu dilakukan.Teknik analisis data yang digunakan adalah teknik analisis deskriptif kualitatif dan teknik analisis deskriptif kuantitatif yang mendeskripsikan hasil uji validitas, dan praktikalitas modul matematika berbasis kontekstual terintegrasi ilmu keislaman.

${ }^{25}$ Punaji Setyosari, Metode Penelitian Pendidikan Dan Pengembangan (Jakarta: Kencana, 2010), 174. 


\section{Deskripsi Hasil Pengembangan Modul Matematika Berbasis Kontekstual Terintegrasi Ilmu Keislaman}

Tahap desain produk ini merupakan tahapan untuk membuat rancangan media pembelajaran yang mengacu pada analisis kebutuhan. Setelah selesai pembuatan desain modul, kemudian modul yang dikembangkan divalidasi oleh ahli desain media pembelajaran dan ahli materi pembelajaran. Validasi ahli dilakukan untuk mengetahui apakah produk yang dikembangkan secara rasional layak atau tidak. Berikut adalah tabel hasil analisis angket penilaian ahli media

Tabel 1.Hasil Angket Penilaian Media

\begin{tabular}{|c|c|c|c|c|c|c|}
\hline \multirow{2}{*}{$\begin{array}{c}\text { No. } \\
\text { Komponen }\end{array}$} & \multicolumn{2}{|c|}{$\begin{array}{l}\text { Skor Setiap } \\
\text { Komponen }\end{array}$} & \multirow[t]{2}{*}{ Jumlah } & \multirow{2}{*}{$\begin{array}{l}\text { Skor } \\
\text { Ideal }\end{array}$} & \multirow{2}{*}{$\begin{array}{l}\text { Perse } \\
\text { ntase }\end{array}$} & \multirow{2}{*}{ Kriteria } \\
\hline & Ahli 1 & Ahli 2 & & & & \\
\hline 1 & 4 & 3 & 7 & 10 & $70 \%$ & Layak \\
\hline 2 & 4 & 4 & 8 & 10 & $80 \%$ & Layak \\
\hline 3 & 3 & 5 & 8 & 10 & $80 \%$ & Layak \\
\hline 4 & 4 & 5 & 9 & 10 & $90 \%$ & Layak Sekali \\
\hline 5 & 4 & 4 & 8 & 10 & $80 \%$ & Layak \\
\hline 6 & 3 & 5 & 8 & 10 & $80 \%$ & Layak \\
\hline 7 & 4 & 4 & 8 & 10 & $80 \%$ & Layak \\
\hline 8 & 4 & 4 & 8 & 10 & $80 \%$ & Layak \\
\hline 9 & 5 & 4 & 9 & 10 & $90 \%$ & Layak Sekali \\
\hline 10 & 3 & 4 & 7 & 10 & $70 \%$ & Layak \\
\hline 11 & 5 & 5 & 10 & 10 & $100 \%$ & Layak Sekali \\
\hline 12 & 4 & 4 & 8 & 10 & $80 \%$ & Layak \\
\hline 13 & 4 & 4 & 8 & 10 & $80 \%$ & Layak \\
\hline 14 & 4 & 4 & 8 & 10 & $80 \%$ & Layak \\
\hline 15 & 5 & 5 & 10 & 10 & $100 \%$ & Layak Sekali \\
\hline 16 & 5 & 5 & 10 & 10 & $100 \%$ & Layak Sekali \\
\hline 17 & 4 & 4 & 8 & 10 & $80 \%$ & Layak \\
\hline 18 & 5 & 5 & 10 & 10 & $100 \%$ & Layak Sekali \\
\hline Jumlah & 74 & 78 & 152 & 180 & & \\
\hline $\begin{array}{l}\text { Skor Tiap } \\
\text { Ahli (\%) }\end{array}$ & $82 \%$ & $87 \%$ & & & & \\
\hline Interpretasi & $\begin{array}{l}\text { Layak } \\
\text { Sekali }\end{array}$ & $\begin{array}{l}\text { Layak } \\
\text { Sekali }\end{array}$ & & & & \\
\hline
\end{tabular}


Berdasarkan perhitungan, jelas terlihat bahwa persentase keseluruhan dari penilaian para ahli desain media pembelajaran adalah layak sekali, karena berada pada rentang $81 \%$ sampai 100\%, sehingga media pembelajaran tidak memerlukan revisi. Namun komentar dan saran ahli desain materi pembelajaran dijadikan bahan pertimbangan untuk menyempurnakan materi pembelajaran. Berdasarkan komentar dan saran dari para ahli terdapat beberapa komponen modul pembelajaran matematika yang sebaiknya direvisi. Hal ini dilakukan agar produk pengembangan modul matematika yang dihasilkan menjadi lebih baik. Berikut ini disajikan beberapa contoh komponen produk yang direvisi.
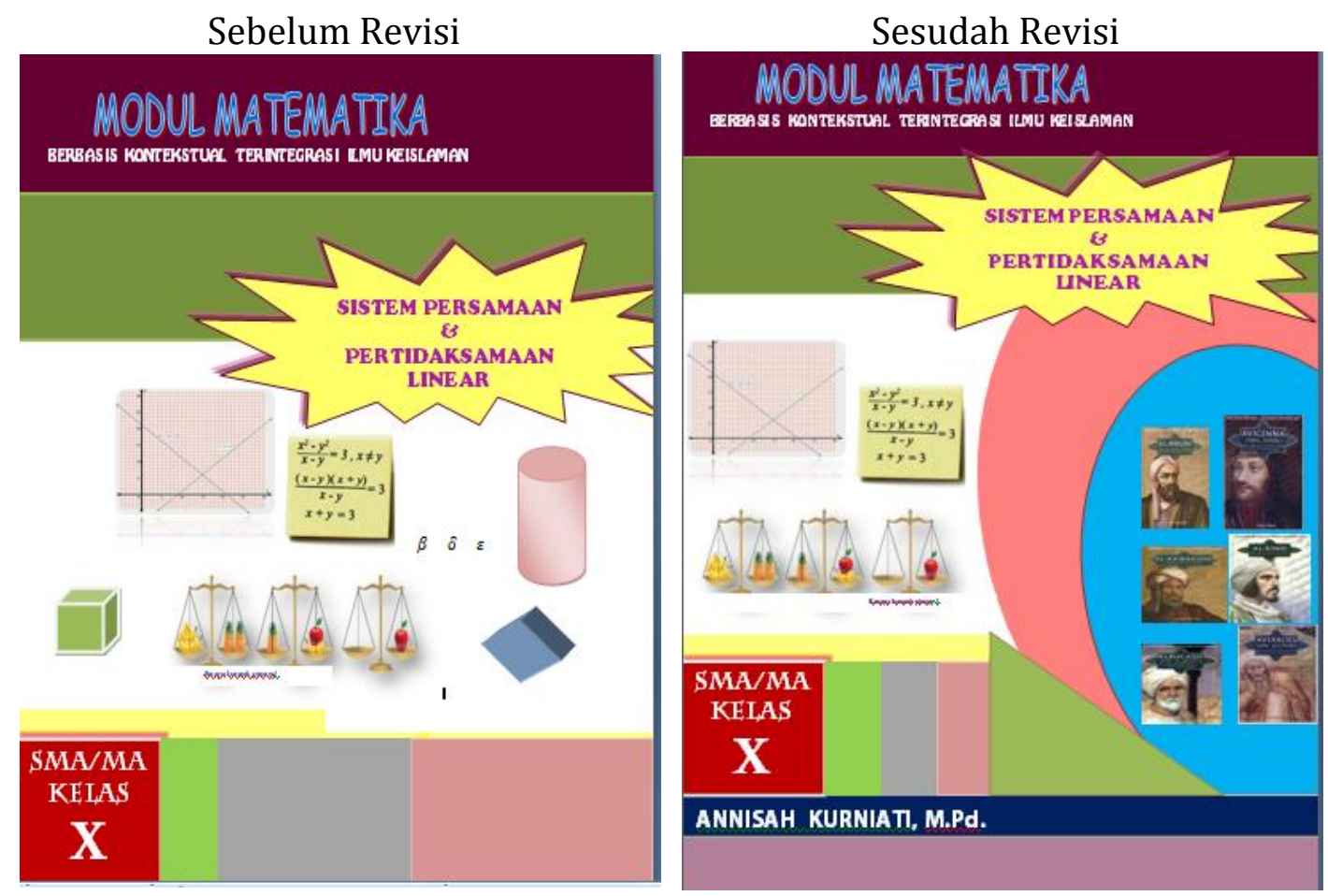


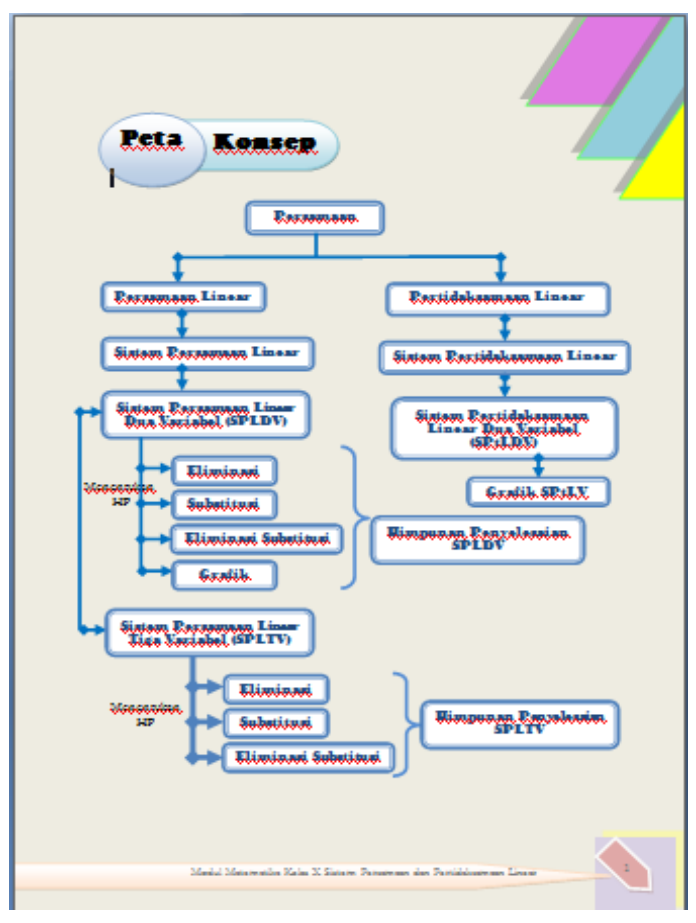

TABEL 2 , SELLSAIAN DAN BUKAN SELESAIAN ATAS MASALAH BU AFFFAH

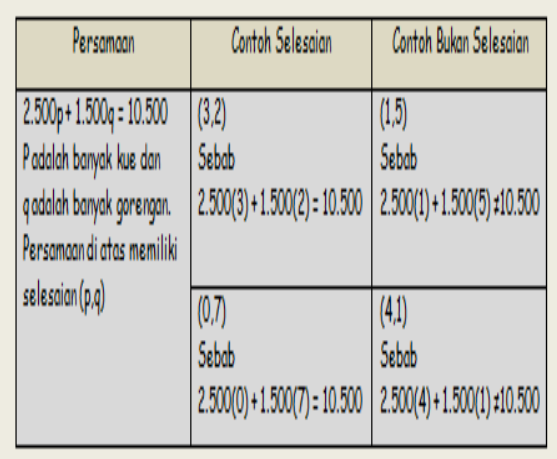

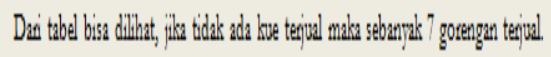

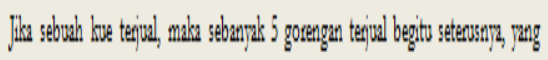

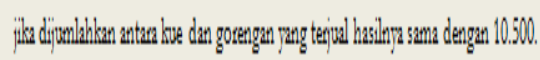

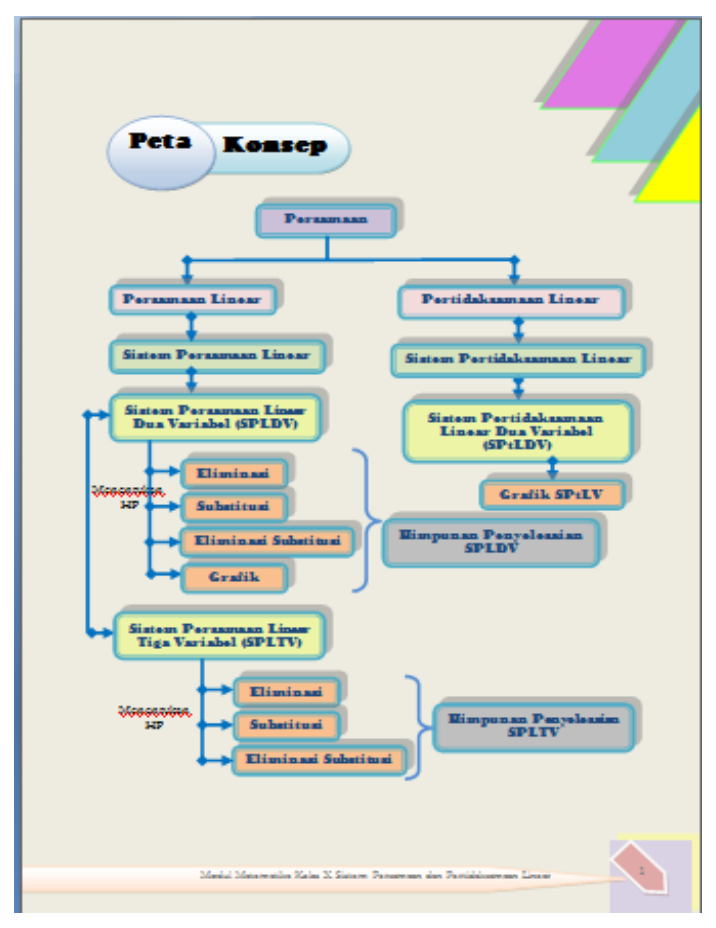

TABEL 2, SELESAIAN DAN BUKAN SELESAIAN ATAS MASALAH BU AFIFAH

\begin{tabular}{|c|c|c|}
\hline Persanomen & Conton Selession & Conton Bukan Selesion \\
\hline \multirow{2}{*}{ 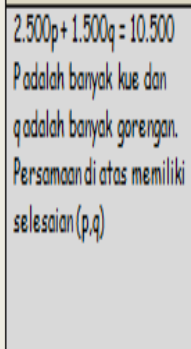 } & $\begin{array}{l}(3,2) \\
5 e 6600 \\
2.500(3)+1.50(2)=10.500\end{array}$ & $\begin{array}{l}(1.5) \\
\text { Seboct } \\
2.500(1)+1.500(5) \pm 10.500\end{array}$ \\
\hline & $\begin{array}{l}(0,7) \\
5 \text { sebob } \\
2.500(0)+1.500(7): 10.500\end{array}$ & $\begin{array}{l}(4.1) \\
\text { Sebobo } \\
2.500(4)+1.50(1 .) \neq 10.500\end{array}$ \\
\hline
\end{tabular}

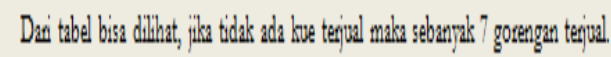

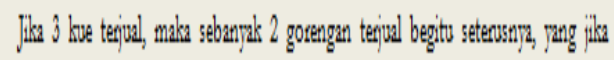

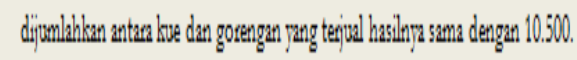

Gambar 1. Modul Pembelajaran Matematika Sebelum dan Sesudah Direvisi 
Setelah modul pembelajaran matematika berbasis kontekstual terintegrasi ilmu keislaman melalui uji kelayakan oleh para ahli desain media pembelajaran dan ahli materi pembelajaran. Selanjutnya modul matematika tersebut dilakukan uji coba pemakaian produk dalam proses pembelajaran melalui angket untuk mengetahui kelayakan modul tersebut. Berdasarkan perhitungan hasil analisis angket tersebut, yaitu diperoleh persentase secara klasikal sebesar $84,87 \%$. Jelas terlihat bahwa persentase keseluruhan dari penilaian para siswa adalah layak dan valid sekali, karena berada pada rentang $81 \%$ sampai $100 \%$. Dengan demikian modul pembelajaran tidak memerlukan revisi. Namun komentar dan saran para siswa dijadikan bahan pertimbangan untuk menyempurnakan materi pembelajaran. Menurut para siswa tersebut, modul matematika ini memiliki tampilan fisik yang baik dan menarik. Memiliki tingkat kejelasan yang baik antara petunjuk penggunaan modul, tujuan pembelajaran, paparan materi, rangkuman, tugas, tes formatif, lembar kerja, dan evaluasi dalam bahan ajar modul matematika. Sehingga uraian materi, contoh-contoh, tugas, tes formatif, lembar kerja, dan evaluasi mudah dipahami oleh siswa.

\section{Penutup}

Berdasarkan hasil penelitian yang telah dilakukan dapat disimpulkan bahwa telah dihasilkan modul matematika berbasis kontekstual terintegrasi ilmu keislaman pada materi Sistem Persamaan dan Pertidaksamaan Linear menunjukkan modul valid dan praktis untuk digunakan di SMA IT Azzuhra Islamic School

Berdasarkan penelitian yang telah dilakukan dan keterbatasan penelitian, maka peneliti menyarankan hal-hal berikut ini:

1. Peneliti menyarankan agar modul ini digunakan dalam pembelajaran materi materi Sistem Persamaan dan Pertidaksamaan Linear kelas X karena telah diuji cobakan dengan hasil yang baik.

2. Penggunaan modul matematika ini dikolaborasikan dengan metode pembelajaran matematika yang menarik lainnya agar pembelajaran menjadi lebih bervariatif.

3. Modul matematika berbasis kontekstual terintegrasi ilmu keislaman ini dikembangkan lebih lanjut dengan melakukan eksperimen menggunakan kelas pembanding agar kualitas modul ini benar-benar teruji dalam hal pemanfaatannya. 


\section{Pengembangan Modul Matematika ...}

4. Peneliti menyarankan bagi peneliti selanjutnya dapat mengembangkan modul matematika kontekstual terintegrasi ilmu keislaman pada materi yang sama atau berbeda dalam meningkatkan kemampuan berpikir kritis. Sehingga modul ini dapat dijadikan sebagai bahan ajar yang dapat digunakan dalam proses pembelajaran.

\section{Daftar Pustaka}

Abdusysyakir. Ada Matematika Dalam Al-Qur'an. Malang: UIN Malang Press, 2006.

_-_. "Pentingnya Matematika Dalam Pemikiran Islam." UIN Malang, 2009.

Ali. "Integrasi Pendidikan Nilai Islam Dalam Pembelajaran Matematika Di Sekolah Menengah Pertama/Madrasah Tsanawiyah Sebagai Upaya Pembinaan Akhlak Siswa." ITB Bandung, 2013.

A.Pribadi, Benny. Desain Dan Pengembangan Program Pelatihan Berbasis Kompetensi. Jakarta: Prenada Media Group, 2014.

_-_. Model Desain Sistem Pembelajaran. Jakarta: Dian Rakyat, 2009.

Depdiknas. Pendekatan Kontekstual (Contextual Teaching and Learning). Jakarta: Direktorat Pendidikan Lanjutan Pertama, 2002.

Habibi, Muhammad. "Pengembangan Modul Pecahan Berbasis Konstruktivisme Dengan Sisipan Karikatur Untuk Kelas IV Sekolah Dasar." In Prosiding Seminar Nasional Pendidikan Matematika UNINUS, Vol. 2. Bandung: Uninus Bandung, 2014.

Hariyani, Mimi. "Strategi Pembelajaran Matematika Madrasah Ibtidaiyah Berintegrasi Nilai-Nilai Islam" 12, no. 2 (Desember 2013).

Hasanah. "Analisis Kemampuan Penalaran Matematika Siswa SMP Melalui Pembelajaran Dengan Pendekatan Kontekstua." Program Studi Pendidikan Matematika PPS UNIMED 4, no. 2 (Desember 2011): 14864.

Mahfuzoh, Siti. "Pengaruh Integrasi Islam Dan Sains Terhadap Matematika." In Proseding Seminar Nasional Matematika Dan Pendidikan Matematika Yogyakarta. Yogyakarta, 2011.

Mbulu, Joseph. Pengajaran Individual. Malang: Yayasan Elang Mas, 2001.

Ag, Moch. Masykur, and Abdul Halim Fathoni. Mathematical Intelegent Cara Cerdas Melatih Otak Dan Menanggulangi Kesulitan Belajar. Yogyakarta: Arruz Media, 2008.

Muchlis, Masnur. Ktsp, Pembelajaran Berbasis Kompetensi Dan Kontekstual. Jakarta: Bumi Aksara, 2007.

MZ, Zubaidah Amir. "Integrasi Nilai Pendidikan Islam Dalam Pendidikan Umum Sebagai Revitalisai Pendidikan Islam." Jurnal Potensia Fakultas Tarbiyah Dan Keguruan Uin Suska Riau 12, no. 1 (June 2013).

___. "Pengembangan Perangkat Pembelajaran Matematika Berbasis Konsep Islami Pada Siswa Kelas V Sekolah Dasar," 2009. LPP UIN Suska Riau.

Nugrahini, Ni Putu Prita. "Pengembangan Modul Ajar Aplikasi Basis Data Dengan Model Pembelajaran Sq3r Untuk Siswa Kelas X Rekayasa 
Perangkat Lunak Di SMK Negeri 1 Negara." JANAPATI: Jurnal Nasional Pendidikan Teknik Informatika 1, no. 3 (Desember 2012).

Oroh, Rully R. "Peningkatan Hasil Belajar Siswa Melalui Penggunaan Bahan Ajar" 2, no. 1 (March 2011).

Pambudi, S. D. "Berbagai Alternatif Model Dan Pendekatan Dalam Pembelajaran Matematika" 1, no. 2 (2007): 39-45.

Parwati, Ni Nyoman. "Pembelajaran Matematika Dengan Pendekatan Kontekstual Pada Siswa SMP Negeri 2 Singaraja (Paradigma Baru Pembelajaran Matematika Sekolah Berorientasi KBK)." Jurnal Pendidikan Dan Pengajaran IKIP Negeri Singaraja 4 (Oktober 2006): 203-223:

Setyosari, Punaji. Metode Penelitian Pendidikan Dan Pengembangan. Jakarta: Kencana, 2010.

Suparni. "Pengembangan Karakter Bangsa Melalui Integrasi Nilai Keislaman Dalam Pembelajaran Matematika." In Prosiding Seminar Nasional Penelitian, Pendidikan, Dan Penerapan MIPA, Fakultas MIPA. Yogyakarta, 2012.

Suryosubroto. Sistem Pengajaran Dengan Modul. Yogyakarta: Bina Aksara, 1983.

"Undang-Undang Sistem Pendidikan Nasional No 20 Tahun 2003, Bab II, Pasal 3," n.d.

Zulkardi. "Pengembangan Perangkat Pembelajaran Berbasis Kontekstual Pokok Bahasan Turunan Di Madrasah Aliyah Negeri 3 Palembang” 3, no. 1 (January 2009). 